$10-2017$

\title{
Book Review: The Killing of Death: Denying the Genocide Against the Tutsis
}

Kee En Chong

University of Cambridge

Follow this and additional works at: https://digitalcommons.usf.edu/gsp

\section{Recommended Citation}

Chong, Kee En (2017) "Book Review: The Killing of Death: Denying the Genocide Against the Tutsis," Genocide Studies and Prevention: An International Journal: Vol. 11: Iss. 2: 121-124.

DOI:

http://doi.org/10.5038/1911-9933.11.2.1462

Available at: https://digitalcommons.usf.edu/gsp/vol11/iss2/16

This Book Review is brought to you for free and open access by the Open Access Journals at Digital Commons @ University of South Florida. It has been accepted for inclusion in Genocide Studies and Prevention: An International Journal by an authorized editor of Digital Commons @ University of South Florida. For more information, please contact digitalcommons@usf.edu. 
Book Review: The Killing of Death: Denying the Genocide Against the Tutsis

\author{
Kee En Chong \\ University of Cambridge \\ Cambridge, United Kingdom
}

The Killing of Death: Denying the Genocide Against the Tutsis

Roland Moerland

Antwerp, Intersentia, 2016

387 Pages; Price: \$106.80 Paperback

Reviewed by Kee En Chong

Wolfson College, University of Cambridge

In the infamous Barayagziza et al. ("Media cases") case, a witness described the broadcasts from the radio station, Radio Télévision Libre des Mille Collines (RTLM), as encouraging the citizenry to "continue to search for those people [the Tutsis] and kill them so that future generations would have to actually ask what Inyenzis [cockroaches] looked like, or, ultimately, what Tutsis looked like." ${ }^{1}$

If speech can precipitate the slaughter, how does speech about the slaughter figure in a genocide? And what about those who would deny the killing altogether? Genocide denial, argues Moerland in his incendiary book, The Killing of Death, is the final step following the final solution. More than the erasure of people, it is the erasure of "the death of the victims...eradicating all traces of death and of murder." ${ }^{2}$ Whereas genocide was the killing of life, denial is the killing of death. If genocide is the annihilation of a people, denial of it, he reasons, should also constitute genocide.

Moerland provides a valuable insight into an overlooked part of the process of genocide. Far too often, commentators tend to consider genocide denial as just an afterthought to the murder. ${ }^{3}$ Moerland reminds us that genocide denial often occurs concurrently with the perpetuation of genocide, and may indeed pre-date it; as the convicted radio personalities in Barayagwiza demonstrate, the dehumanization and the distortion of fact necessary to whip up a population into a frenzy is a continuing process. ${ }^{4}$ It begins with instigators preaching that genocide victims do not matter, and it ends with deniers claiming that genocide victims do not exist.

Drawing upon speech act theory, Moerland shows that such speech is performative, or illocutionary. Where claims are made that the genocide never happened, deniers perform their speech is not empty words echoing in the void, but an illocutionary act of labeling - the dehumanization of victims by denial. ${ }^{5}$ Where there is denial of genocide, survivors are forced to re-live their victimization in order to re-assert their victimhood. But speech also has perlocutionary consequences, which Moerland terms genocide denial. In contrast to denial of genocide, words can not only do emotional harm, they can also convince ordinary men to pick up sticks and stones to kill their fellow human beings. ${ }^{6}$

The reminder that speech never exists in a vacuum has never been more current. Xenophobia and racist speech no longer remains confined within far-right groups in the United States and Europe. Increasingly, mainstream candidates trade upon prejudice and hatred and stoke fears of violence against minorities with every slur. ${ }^{7}$ Although Moerland situates his analysis within the

\footnotetext{
${ }^{1}$ Prosecutor v. Barayagwiza et al., Judgment and Sentence, Trial Chamber I, ICTR-99-52, 3 Dec, 2003, 147.

${ }^{2}$ Moerland, The Killing of Death, 99.

${ }^{3}$ Ibid., 102.

${ }^{4}$ Ibid., 106.

${ }^{5}$ Ibid., 223.

${ }^{6}$ Ibid., 91, 107.

${ }^{7}$ Engy Abdelkader, When Islamophobia Turns Violent: The 2016 U.S. Presidential Elections (Washington D.C.: The Bridge Initiative, 2016), available at http://bridge.georgetown.edu/when-islamophobia-turns-violent-the-2016-u-s-presidentialelections/.
} 
genocide against the Tutsis - it is a pertinent example of how the auspices of liberalism's protection of minorities may often run up against its defense of the ideals of free speech.

It is in this vein that another more evocative, even controversial, argument is raised. Genocide deniers, Moerland claims, are not merely isolated to those who would outright say "there was no genocide," they rank among their number those who make implicit illocutionary statements such as those who say "it was started by the Tutsis," or "it was not genocide, but a civil war," and even those suggesting "there was a genocide against the Hutus too by the Rwandan Patriotic Forces (RPF)." 8

Moerland takes aim at academics such as Herman, Peterson and Chomsky, accusing them of forming linguistic community with, and indeed enacting, primary genocide denial. Others, such as Davenport and Lemarchand, who question events such as the downing of President Habyarimana's plane, Moerland considers to lack sufficient genocidal intent. They nevertheless fall into a category of secondary genocide denial by facilitating the process and violence of genocide. ${ }^{9}$

At times, Moerland acknowledges that his accusations might stretch the incredulity of the reader. Even when stressing that he is not applying the legal definition for genocidal intent, Moerland appears to suggest that the academics have similar intent as génocidaires, or at least that current legal definitions are inadequate. ${ }^{10}$ Here, his analysis falters. Castigating his targets for implicit genocide denial is one thing; implying culpability in the act of genocide is quite another, and possibly quite inappropriate. Indeed, the law has as much to instruct his analysis as the other way around.

As the ICTR in Barayagwiza points out, not all potentially dangerous speech can be said to constitute incitement, but rather depends entirely upon the context the speech is situated in. ${ }^{11}$ Incitement further requires distribution to a mass audience "directly call[ing] for the commission of genocide."12 Far from incitement or malicious denial, academics such as Chomsky, and journalists such as Snow, are writing as a matter of public news, or ascertaining historicity. While their writings might be wrongheaded and contrary to the vast weight of historical evidence, both its context and actual effects matters. ${ }^{13}$ Perhaps more than a mere possibility of facilitating genocide and causing emotional violence might be necessary before academics and journalists should be considered bona fide genocide deniers. ${ }^{14}$

As for intentionality, Moerland himself concedes that they are writing primarily to critique a perceived U.S. imperialism. ${ }^{15}$ Of course, perpetrators of genocide themselves often attempt to rewrite history, or lambast U.S. imperialism, but it is precisely because intention is paramount that genocide is a crime of ulterior intent and not the other way around. It is possible the same legal considerations should hold for whether we decide to label some misguided, and others genocide deniers. For one, blurring the requirement for intentionality threatens to collapse Moerland's own delineation between secondary and primary genocide denial. ${ }^{16}$

For another, accusing research of genocidal intent on the basis of its putative complicity with genocide denial raises some very difficult questions; not least the question of why it would not also be legitimate for these same academics to label him a stooge of U.S. imperial interests. ${ }^{17}$ Indeed, a case in point is where Moerland himself acknowledges that there may well be legitimate concerns about potential American human rights violations and imperialism. ${ }^{18}$

\footnotetext{
${ }^{8}$ Moerland, 119.

${ }^{9}$ Ibid., 212, 222, 107.

${ }^{10}$ Ibid., 212, 213.

${ }^{11}$ Prosecutor v. Barayagwiza et al., Judgment, Appeals Chamber, ICTR-99-52-A, 28 Nov, 2007, para.711, para.705.

${ }^{12}$ Ibid., para. 693.

${ }^{13}$ Moerland, 227.

${ }^{14}$ Ibid., 251.

${ }^{15}$ Ibid., 226, 328.

${ }^{16}$ Ibid., 107.

${ }^{17}$ Ibid., 199.

${ }^{18}$ Ibid., 225.
} 
The veil of academic research and journalistic credence - no matter how badly conducted - is one we grant with veneration and lift only with reluctance. Moerland is absolutely right to critique their writings as recycling genocide denial and capable of inflicting emotional violence, but there are times where his critiques veer dangerously close to being ad hominem attacks despite claims to the contrary. ${ }^{19}$ Imputing an intention to deny genocide or a willingness to facilitate genocide qua emotional violence on academics does little to advance historical discourse. ${ }^{20}$

Inter-relatedly and as problematically, Moerland suggests that even in the realm of discourse, some truths can never be questioned. ${ }^{21}$ He eschews a notion of objectivity that would permit the "hear[ing] of critical arguments" that would challenge crucial elements of historical fact of the genocide against the Tutsi. ${ }^{22}$ The approach of the Enlightenment, he claims, leads to a radical subjectivity where all truths are equally valid and allows genocide deniers to thrive within its interstices. ${ }^{23}$ But even with the potential for abuse, the common plateau of discourse is not simply about hearing both sides. As the U.S. Supreme Court Justice, Oliver Wendell Holmes, put it, "the best test of truth is the power of thought to get itself accepted in the competition." ${ }^{24}$ Far from a nonchalant approach to an objective truth, discourse permits all arguments to be heard precisely because it adopts a radical humility, coupled with an ardent passion for securing the truth. ${ }^{25}$

Most significantly, whether speech is labeled genocide denial or incitement has powerful consequences for criminalization as it permits the force of the State - the same force often used in genocides - to be leveled against purported perpetrators. Two of the defendants in Barayagwiza were ultimately convicted of direct and public incitement to commit genocide - the decision by the ICTR was highly controversial. Commentators have suggested that the judgments gave further vigor to prosecutions by African governments eager to suppress free speech and the media. ${ }^{26}$

To be fair, Moerland is careful to note that criminalization should not be resorted to easily, but there are points where his support for criminalization is manifestly problematic. ${ }^{27}$ The crime of genocide denial in Rwanda is already so vaguely legislated as to potentially capture legitimate critiques of the Rwandan government by human rights advocates. ${ }^{28}$ As Moerland observes, "[c] alls for justice for RPF crimes do not automatically amount to genocide denial...[t]o denounce people or hold them criminally liable for using phrases solely because these phrases are also often used in the context of a broader denial discourse would virtually amount to guilt by association." 29 Despite his charitable views vis-à-vis human rights advocates, it is unclear why the fine line, if at all drawn, permits their critiques and not others.

Criminalization, coupled with denunciations by official figures such as Rwandan President Kagame, of the advocacy of Amnesty International and Human Rights Watch as trash and pathetic, can only lead to an atmosphere of self-censorship. ${ }^{30}$ Moerland even goes as far as to suggest that while "[speaking] truth to power is surely important...it should preferably be done" with a different rhetoric and at a time more amenable to the palate of the ruling régime. ${ }^{31}$ Why human rights advocates should follow his prescriptions is far from clear; there is no inconvenient time for the truth, only inconvenient truths, and it is especially those that must be heard, no matter how they are phrased.

\footnotetext{
${ }^{19}$ Ibid., 337.

${ }^{20}$ Ibid., 212.

${ }^{21}$ Ibid., 325.

${ }^{22}$ Ibid., 323.

${ }^{23}$ Ibid., 324.

${ }^{24}$ Abrams v. United States, 250 US 616, 631 (1919) (Oliver Wendell Holmes dissenting).

${ }^{25}$ Ibid., 631.

${ }^{26}$ Open Society Justice Initiative, Amicus Curiae Brief in The Prosecutor v. Barayagwiza, 2006, 8,

https://www.opensocietyfoundations.org/sites/default/files/ictr-nahimana-amicus-brief-20061215.pdf

${ }^{27}$ Moerland, 335.

${ }^{28}$ Ibid., 287.

${ }^{29}$ Ibid., 289.

${ }^{30}$ Ibid., 287.

${ }^{31}$ Ibid., 291.
} 
Moerland further asserts that criminal defense teams are equally complicit in genocide denial and that prosecutions of the defense counsel at the ICTR for genocide denial was legitimate. ${ }^{32}$ However, regardless of whether such speech occurs inside or outside a courtroom, the immunity granted to lawyers is precisely meant to guarantee the sacred right to a fair trial. ${ }^{33} \mathrm{Up}$ until clear risks of violence from denial materialize, it is unclear why they should override the actual rights of an accused person.

Most worryingly, Moerland argues that criminalization might not be appropriate, not because the legislation is already overwrought, but presumably because there has not been sufficient criminalization of genocide denial for its emotional harm. ${ }^{34}$ Coupled with the admittedly vague ambit of the crime of genocide denial in Rwanda, and the possibility of political suppression of dissidents, the views of Moerland amount to very alarming implications for freedom of speech and the pursuit of justice for all.

There is no doubt Moerland is right that genocide denial should be castigated for its propensity to inflict emotional violence and facilitate genocide. The speech of the RTLM radio personalities may on the one hand be construed as an exercise of the right to free speech, and on the other hand wielded as a dangerous weapon causing genocide and genocidal harm. It is a veritable doubleedged sword of Damocles.

There should be little sympathy for those who have been categorically demonstrated to have incited genocide, but it is unclear that the sword should also cut against genocide deniers, who whilst undeniably unpalatable, continue to deserve the protections of freedom of speech. Those protections are not for their benefit, but for all the others - human rights advocates and those seeking justice for crimes from all quarters. "It is a fair summary of history," it has been observed, "to say that the safeguards of liberty have frequently been forged in controversies involving not very nice people." 35

Moerland does some illuminating work in The Killing of Death; it is a careful, reflective study and does much to broaden the discourse about the effects of denying the truth of the genocide against the Tutsis. But some of his conclusions deserve close scrutiny. The historical fact of the genocide does need to be safeguarded, but it is dis-agreement within academia and the press that provides the surest guarantee; "[t]o many this is, and always will be, folly; but we have staked upon it our all." ${ }^{36}$ Even in the context of the ultimate crime, only one ultimate truth remains certain - the freedom to speak.

\footnotetext{
${ }^{32}$ Ibid., 277.

${ }^{33}$ See for example International Criminal Tribunal for Rwanda, Note Verbale to the Ministry of Foreign Affairs and Cooperation of the Government of Rwanda, Office of the Registrar, ICTR-RO-175, 15 Jun. 2010.

${ }^{34}$ Moerland, 336.

${ }^{35}$ United States v. Rabinowitz, 339 US 56, 70 (1950) (Felix Frankfurter concurring).

${ }^{36}$ United States v. Associated Press, 52 F Supp 2d 362, 372 (SDNY 1943) (Learned Hand).
} 